\title{
Hepatic veno-occlusive disease
}

INSERM

\section{Source}

INSERM. (1999). Orphanet: an online rare disease and orphan drug data base. Hepatic veno-occlusive disease. ORPHA:890

Hepatic veno-occlusive disease (hepatic VOD) is a condition resulting from toxic injury to the hepatic sinusoidal capillaries that leads to obstruction of the small hepatic veins. 